\title{
Peace through Tourism: A Critical Look at Nepalese Tourism
}

\author{
Pranil Upadhayaya \\ pranilupadhayaya@yahoo.com
}

\begin{abstract}
Tourism, the world's largest and one of the fastest developing economic sectors, virtually affects every region and nation of the world due to its potential contribution to international understanding and poverty reduction. Nepal is no exception. The remarkable growth of tourism at present (peace time) has been progressing through its four progressive theoretical models/platforms (e.g., advocacy, cautionary, adaptancy and knowledge-based platforms) with each having both peace potential and limitation. In this scenario, there is likely growing attention and look at tourism with a passion for its peace prospective.
\end{abstract}

'Peace', a vital and most cherished dream of humanity, is a state that not only indicates the absence of direct violence but also sustains peaceful relationships among all levels and segments of society and between society and nature.

Tourism is sensitive to conflict and responsive to peace. There are both opportunities and challenges for the peace responsiveness of tourism in Nepal. Nepalese tourism, which passed through a decade long (1996-2006) armed conflict, serves a concrete illustration of this nexus of tourism and peace with the dual attributes of tourism for conflict and peace. However, this paper envisages that it is a community-based village tourism supported by sustainable structures and actions, backed by proper implementations of tourism regulations, framed with appropriate codes of conduct and materialized by the integrated effort and partnership actions of all (non-scientific and scientific) stakeholders that can be the most viable option for achieving the noble goal of peace through tourism in Nepal. In this context, this paper exemplifies it with an innovative example of a research-linked and empirically executed case of Machhapuchchhre Model Trek (MMT) in Western Nepal. MMT is footed at the knowledgebased platform on transdisciplinary approach in which the scientific (e.g., researchers) and both academic and non-academic (e.g., local communities, local government, tourism practitioners, tourists, etc.) actors approached in an integrated effort to transform local tourism initiatives as peace promoting and conflict mitigating.

This paper finally recommends the knowledge-based approach to Nepalese tourism as important not only for bridging the earlier three platforms but also for fulfilling the dual (mass as well as small-scale community-based village tourism) needs of Nepalese tourism at present and thus succeed on peace aspirations through tourism.

Key words: Tourism; Tourism Progressive Models; Peace through Tourism; Tourism Practices \& Transdisciplinary Approach 


\section{Introduction}

The success of Jana Andolan II (People's Revolution II) followed by the signing of the Comprehensive Peace Agreement (CPA) between the then Communist Party of Nepal - Maoist (CPN-M), (note 1) and the government in 2006 have taken Nepal into a new era of peace process and paved the way for economic revolution. The unlimited endemic natural and traditional cultural attractions spread in foremost rural geographical areas of Nepal, unique hospitality attributes of Nepalese people, low capital intensive nature of Nepalese tourism and its high labor tilting and the resilient nature offer tremendous potentials and optimisms for post-conflict socio-economic transformation and peace dividends through tourism. However, the ups and downs (fluctuations) in Nepalese tourism during the heightening of the armed conflict from 2001-2005, political instabilities (e.g., changes of nine prime ministers in a period of ten years from 1991-2000) in the mainstream national politics in one-and-half decades of democracy from 19902005 and the fragile peace process in the post-conflict period after the historical peace accord of 2006 at present coinciding with the recent major shifts in national tourism policies and programs (e.g., introduction of New Tourism Policy 2009, Home Stay Tourism Operation Work Procedure 2010 and the formal launching of Nepal Tourism Year 2011, a mega national tourism event to revive the ShangriLa image of Nepal as a tourist destination) have raised both curiosities (hopes) and question marks (doubts) about the role and upshot of tourism for prosperity and peace. This has further hyped the debate on peace through tourism with positive, negative and indifferent perceptions.

With this background, having the state of a tripartite complex nexus between tourism, conflict and peace in the Nepalese context, this paper first provides a broad definition of peace and relates its role on tourism. In an attempt to explore the reciprocal relationship between tourism with peace and converse relationship between tourism and conflict, it evaluates some case studies underpinning. Methodologically, this paper has used qualitative and quantitative data collected through secondary and primary sources of information from the research-based work in the years 2009-2010 and analyzed accordingly (note 2 for supplementary information on methodology).

In exploring the relationship of tourism with peace, this paper has particularly attempted to address the following questions:

1) What is the relationship between peace and tourism? How is the reflection of the peace prospective of tourism? Is this relation reciprocal?

2) What are their practical implications for peace through tourism in the Nepalese context?

3) What are the innate opportunities and apparent challenges for peacebuilding through tourism in Nepal? What can be a rational model which is conflict mitigating and peace promoting through tourism in Nepal? 
While addressing the above questions, the author came across some remarkable positive insights, experiences and reflections on peace responsiveness of village tourism which is community-based. In this context and through the empirical learning experience of a community-based village tourism, Machhapuchchhre Model Trek (MMT) in Western Nepal under the knowledge-based platform, this paper envisages the high prospective of community-based village tourism on participatory and sustainable appearances for promoting peace through tourism in Nepal.

\section{Peace Theory and its Role on Tourism}

Peace researchers and educators through various publications around the world at present are dealing with some major peace-related emerging issues such as structural violence, cultural violence, personal violence, racism, ethnic conflict, global warming, environmental destruction, north-south relations, sustainable development, debt and global poverty, population growth, resource scarcity, feminist perspective on peace, militarism, political violence and human rights, etc. (Arai, 2010; Bodhi, 2008; Galtung 1996; Moufakkir and Kelly, 2010; Rees, 2003; Salzar, 2006; Satani, 2003).

Peace has been normally defined as negative and positive (Galtung, 1996; Moufakkir and Kelly, 2010). There is presence of structural and cultural violence in negative peace (Galtung, 1996). Positive peace is a state with neither overt violence nor the more subtle phenomenon of underlying structural violence. It emphasizes the presence of justice, harmony and equity within and between societies. Referring to the multifaceted nature of peace, Moufakkir and Kelly (2010) envisage peace as a hierarchical concept with participatory peace in the highest position (figure 1).

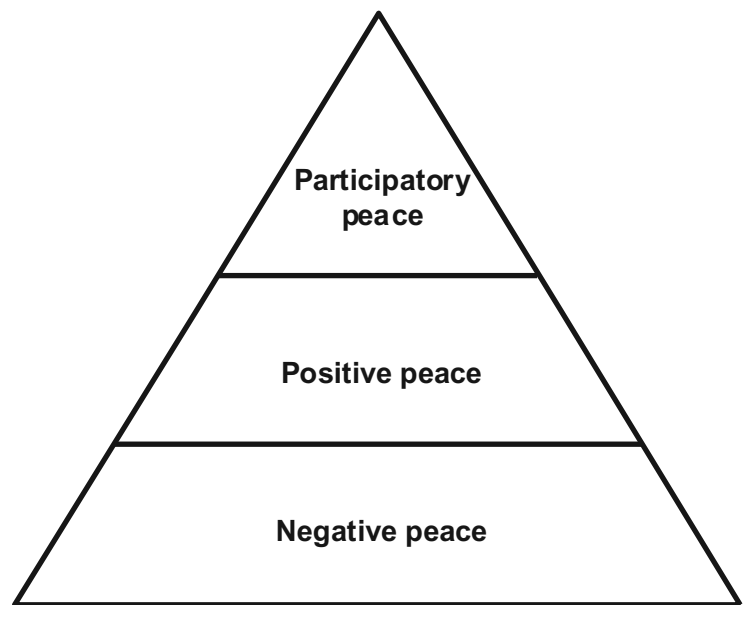

Figure 1: The Peace hierarchy

Source: Moufakkir and Kelly (2010) 
Peace is an essential precondition for travel and tourism and all aspects of human growth and development (IIPT, 2011a). The tourism industry, which is often known as a peace and development industry, thrives in a peaceful environment. It is found to have a close relationship with tourism (Adhikari, 2005; Bhattarai \& Dahal, 2007; Grandon, 2007; NTB, 2008; Upadhayaya, 2008; Upreti and Upadhayaya, 2010).

The relationship between tourism and peace has also been endorsed by a number of international initiations (e.g., The UN Declaration of Human Rights in 1948, International Bureau of Social Tourism in 1963, The Helsinki Accord in 1975, World Tourism Organization's Tourism Bill of Rights \& Tourist Code in 1985, United Nations World Tourism Organization's Sustainable Tourism-Eliminating Poverty 2003, etc.). Amidst the various desires and commitments for peace through tourism, the United Nations (UN) has identified tourism as an important means of creating peace in the world. The UN has focused on Peace and Tourism in its conference on Environment and Development on June 14, 1992, and made a note in the Amman Declaration on 'Peace through Tourism' adopted at the Global Summit on Peace through Tourism on November 11, 2000 (IIPT, 2011a; IIPT, 2011b; Kunwar 2006).

The view of Edgel (1990) emphasizing the demand of peace for tourism, even marking as 'peace: passport to tourism', supports the argument for peace through tourism. However, it is imperative that positive peace is largely supportive for the growth of tourism than negative peace. The role of sustainable and participatory tourism is important for the causal relationships of tourism for peace-building.

\section{Peace-building through Tourism: Potentials and Limitations in Nepal}

As a universal phenomenon and integral part of globalization, tourism seeks peace, stability, and tranquility for its development and prosperity (Mihalic, 1996; Tarlow, 2006). On the other hand, tourism being a powerful socio-economic force and responsive to peace can also play a potential role of benefactor to mitigate conflict and support post-conflict peace-building. However, it not only has such potentials but also limitations for peace building which have been discussed in the works of a number of scholars by referring to case studies from Australia, China-Taiwan, Croatia, Israel-Palestine, Rwanda, USA, etc. (Alluri 2009; Din, 1988; D’Amore, 1988 \& 2007; Eriksson, Noble, Pattullo, \& Barnett, 2009; HigginsDesbiolles, 2006, Higgins-Desbiolles \& Blanchard 2010; Issac, 2010; Leitner, 1999; Satani, 2003).

\section{Potentials for peace through tourism availing in Nepal:}

The potential for peace through tourism in Nepal was realized in the past and it is envisioned for future too. The launching of a mega tourism project (e.g., a US\$ 18.72 million project titled 'Tourism for Rural Poverty Alleviation Programme' launched during 2001-2005) in an effort for rural poverty alleviation, appearance 
of tourism as a small-scale uninterrupted activity and the responses (e.g., through various press conferences, press releases, industry interactions, etc.) of the private sector tourism actors for the destination image-building even during the armed conflict and collective roles of tourists and tourism entrepreneurs by showing solidarity through 'Democratic Tourism Entrepreneurs Association' for the restoration of peace and democracy during the 19 days of the successful Jana Andolan II are a few examples of the efforts for peace through tourism made in the past in Nepal (BBC, 2004; Dhakal, 2005; Dhakal, Khadka, Sharma, \& Choegyal, 2007; Grandon, 2007; Pandey, 2008; Sherpa, 2005; Upadhayaya, Müller-Böker, \& Sharma, 2010).

The launching of the NTY 2011, a mega national tourism event with slogans like 'Together for Tourism', 'Tourism for Prosperity', and 'Prosperity for Peace' and also targeting to attract one million tourists in 2011, shows the soaring expectations of tourism for prosperity and peace in Nepal. Realizing poverty and inequality as the root cause of conflict and in aid of peace through tourism, the government has come up with some new initiations to widen the participations in tourism and give access to the benefits of tourism to rural communities, who are unsurprisingly much improvised. The diversification of tourism in villages through homestay provision by approving a Homestay Sanchalan Karyavidhi 2067 (homestay operation working procedure 2010) in July 2010 based on two modalities - community homestay and private homestay and the usual continuity of VolunTourism and Philanthropic travel are other potentials for peace-building through tourism in Nepal (MoTCA, 2010b).

\section{Limitations for Peace through Tourism in Nepal}

\section{The unequal structure of tourism:}

The spatial distribution of tourism in Nepal is not balanced and it is mainly concentrated on the comparatively few regions with tourist infrastructure (Müller-Böker, 2000). The ruling elites and merchant-class centered in Kathmandu dominate the hotel sector and other services catering to tourists. The industry remain highly centralized and focused in the Kathmandu Valley, comprising the country's three culturally rich urban centers: Bhaktapur (Bhadgaun), Lalitpur (Patan) and Kathmandu (Kantipur) (Bhattarai, Conway, \& Shrestha, 2005). The industry's uneven growth, monopolistic class character, and neglect of rural impoverishment are preventing the promise of tourism on the notion of sustainability, fair participation and peace-building.

Recognizing the domination of tourism by a small number of urban-based elite entrepreneurs at the central level, the government provisioned to plough back certain amount of the revenue to the areas where the revenue was initially generated (NTB, 2005). However, not all frameworks are really operational and it is also not clear how these investments have brought benefits to the local 
people. These issues are resulting in local dissatisfaction and prolonged conflicts and even ensuing with occasional community oppositions (table 1), which are alarming signs for tourist destination image-building and peace perspective of tourism.

\begin{tabular}{|l|l|l|l|}
\hline \multicolumn{1}{|c|}{$\begin{array}{c}\text { Case } \\
\text { study No. }\end{array}$} & Date & \multicolumn{1}{|c|}{ Place } & \multicolumn{1}{c|}{$\begin{array}{c}\text { Nature of local community/workers' } \\
\text { oppositions and consequences }\end{array}$} \\
\hline 1. & $\begin{array}{l}\text { August } \\
2010\end{array}$ & $\begin{array}{l}\text { Lomanthang, } \\
\text { Mustang }\end{array}$ & $\begin{array}{l}\text { Dissatisfaction, and threat to bar tourists from } \\
\text { entering Upper Mustang from October 2010 by } \\
\text { the members of Upper Mustang Youth Society } \\
\text { and other local inhabitants }\end{array}$ \\
\hline 2. & $\begin{array}{l}\text { July } \\
2009\end{array}$ & $\begin{array}{l}\text { Sauraha, } \\
\text { Chitwan }\end{array}$ & $\begin{array}{l}\text { Warning to go in strikes by the members } \\
\text { of Chitwan National Park Middle Region } \\
\text { management committee, forest conservation } \\
\text { committee and other local stakeholders on the } \\
\text { issue of the reopening of 7 resorts located inside } \\
\text { the Chitwan National Park which were closed } \\
\text { on July 16 after the expiration of their operating } \\
\text { licenses. }\end{array}$ \\
\hline
\end{tabular}

Table 1: Examples of community oppositions against unjust tourism practices

Source: Primary information from the field visit in Chitwan (July-August 2009), The Himalayan Times (2009a) and The Himalayan Times (2009b)

It would be relevant to get insights through a short analysis of the above case studies in tourism concerning the uprising of conflict.

\section{Case study 1:}

Before the formal opening of the long restricted areas of Upper Mustang in northern Nepal, it was agreed to plough back 60 percent of the tourist revenue generated from Upper Mustang tourism with tourists' fees of $\$ 700$ (lowered later to $\$ 500$ ) with assurance from political leaders and the then prime minister for its development and heritage conservation (Gurung, 1998, as in Sharma, 2000). The rationale behind the introduction of high-yield tourism to benefit conservation and local development through plough back could not be well effectuated as the assurances were not backed up by an executive order. Out of the total revenue of $\$ 537,600$ earned from tourist entry fee, the government had channelized $\$ 322,560$ for this region in 1993 (Kantipur Editorial, 2010). Similarly, only 4.1 percent of the entry fee could be used by Upper Mustang Conservation Area Development Project in 1998 (Sharma, 2000). It did not release even a penny after that. Nepal (2003, p. 150) mentions that "the idea of channeling a significant proportion of tourism revenue to finance local development projects has not materialized as initially envisioned." The dissatisfied local people organized through Upper Mustang Youth Society decided to launch a movement and bar foreign tourists from entering the region from October 1, 2010 (Pokharel and 
Paudel, 2010).

The Ministry of Home issues the permits to tourists to enter Upper Mustang, collects revenue from each tourist entrance fee and sends it to the Ministry of Finance (MoF). MoF is ultimately responsible for revenue distribution through the National Trust for Nature Conservation (Annapurna Conservation Area Project in case of Mustang).

\section{Case study 2:}

The Dapha 3 (Article 3) of the National Park and Wildlife Conservation Regulation (NPWCR) 2030 (1973) has clearly mentioned to call for open tender to select jungle resort(s) to operate inside the national park through a 35-day tender process (DNPWC, 2004). National Parks and Wildlife Conservation Act (NPWCA) 2029 (1972) has also clearly mentioned to allow to operate resorts inside the national parks through fulfilling the standard working processes (DNPWC, 2004).

The 15-year contracts (since the year 1993) of lease agreement between the government and seven jungle resorts, namely Tiger Tops, Island Jungle Resort, Gaida Wildlife Camp, Machan Wildlife Resort, Temple Tiger Jungle Resort, Chitwan Jungle Lodge and Narayani Safari Lodge located inside the Chitwan National Park (CNP), a UNESCO Natural World Heritage site that shelters endangered wildlife including one-horned rhinos in Chitwan district, expired on July 15, 2009. Prior to this context, a 6-member investigation committee formed under the leadership of Mr. Madhav Acharya, the joint secretary of Ministry of Forests and Soil Conservation, had submitted a study report to then Minister for Forests and Soil Conservation reporting several discrepancies against the legal guidelines laid down by conservation regulations of the NPWCA 2029 (1972) (Bhatta, 2009). There were following recommendations made regarding the jungle resort and conservation matters on January 30, 2009.

- There should be no operation of jungle resorts inside the park. The permanent resorts structures inside the park have negatively affected the free movement and habitat of all kinds of wild animals. This could help to conserve the rare one-horned rhinos of Chitwan known as the "Brand" of Chitwan National Park. Hence, all operating resorts inside the park should be removed.

- A total of 11 tented camps could be operated at a distance of 6 kilometers between two tented camps.

An open conflict arose between those seven hoteliers with their employees (supported by others like Hotel Association of Nepal, Federation of Nepalese Chambers of Commerce and Industry) who demanded that they be allowed to run hotels without calling tenders and national park conservationists (supported 
by others like Secretary of Ministry of Forests and Soil Conservation, members of Chitwan National Park middle region buffer zone management committee, forest conservation committees, all hoteliers outside the national park located in Sauraha, the director general of DNPWC, security forces, the DNPWC and other local stakeholders). The latter preferred free competition to allow hotels inside the park based on existing legal provisions.

This row was well apparent at the policy level at the center in Kathmandu too when the Ministry of Forest and Soil Conservation (MoFSC) openly favored the earlier side and initiated to extend the operation permission of seven hotels, even violating the existing law, whereas the Secretary of MoFSC favored the latter side (Bhatta, 2009). The latter proposed for open competition guided by the jurisdiction of NPWCR 1973, NPWCA 1972 and Buffer Zone Management Regulation. The conflict between the two sides (inside hotels within the park versus conservationists) was long-drawn-out. Around 700 hotel workers of the seven hotels through a 'Joint Labor Struggle Committee' began agitation and even stopped tourists for some time who were entering the CNP via Tandi (EastWest Highway) and Sauraha (Eyewitness by the author; Shrestha \& Shrestha, 2008; The Himalayan Times, 2009b; Tripathi, 2009). The row ended in November 2009 with a special sub-committee formed by the Public Accounts Committee under the legislature-parliament to probe and submit the facts. It came with the following decisions after intense consultation with all stakeholders.

- $\quad$ Renewal of the operating licenses of the hotels with doubling of their tax payable to the government for the space used till December 2011 considering the threat of negative image-building of park tourism with the shortly approaching NTY 2011

- $\quad$ Advice to shift those hotels to middle region. No increment in their royalty for operating license to the government for seven years in case of their relocation within six months.

- $\quad$ Provision for monopoly to run only those seven hotels if they shifted to a new entry point of CNP within one year.

A thorough analysis of the case study of conflict between park tourism and park conservation in CNP reveals that the local population residing in the buffer zone area of CNP has minimally benefited from natural resource use along with tourism in the national park as also revealed by Mishra (1982) and Müller-Böker (1999).

\section{Fragile Peace Process Amidst New Forms of Conflict}

The post-conflict peace process of Nepal is passing through a fragile transition phase which has imposed a number of new structural challenges to the tourism sector to grow and sustain smoothly (Sharma \& Upadhayaya, 2008). A Post 
Editorial (2008) covering a report issued by UN World Food Programme (WFP) states that there were a total of 755 banda (closures) and strikes in the year 2008 in Nepal. Nepal saw 125 days of banda (closures) in various parts of the country called by various political and non-political groups in 2010 (Adhikary, 2010). Because of the uninterrupted state of these internal conflict-related challenges too, the rate of growth in annual tourist arrivals, their average length of stay and the revenue earned from tourism in the post-conflict years, especially in 2008, was negative and/or after 2008 was slow and uneven (table 2).

\begin{tabular}{|c|c|c|c|c|c|c|}
\hline Year & $\begin{array}{c}\text { Number of } \\
\text { international } \\
\text { tourist } \\
\text { arrivals }\end{array}$ & $\begin{array}{c}\% \\
\text { Change } \\
\text { from } \\
\text { previous } \\
\text { year }\end{array}$ & $\begin{array}{c}\text { Average } \\
\text { length of } \\
\text { stay }\end{array}$ & $\begin{array}{c}\% \\
\text { Change } \\
\text { from } \\
\text { previous } \\
\text { year }\end{array}$ & $\begin{array}{c}\text { Revenue } \\
\text { generated } \\
\text { from } \\
\text { tourism } \\
\text { (in US\$ } \\
\text { million) }\end{array}$ & $\begin{array}{c}\% \\
\text { Change } \\
\text { from } \\
\text { previous } \\
\text { year }\end{array}$ \\
\hline 1995 & 363,395 & & 11.27 & & 116.8 & \\
\hline 1996 & 393,613 & 8.3 & 13.50 & 1.98 & 116.6 & -1.71 \\
\hline 1997 & 421,857 & 7.2 & 10.49 & -2.23 & 115.9 & -6.00 \\
\hline 1998 & 463,684 & 9.9 & 10.76 & 2.57 & 152.5 & 31.58 \\
\hline 1999 & 491,504 & 6.0 & 12.28 & 1.41 & 168.1 & 10.23 \\
\hline 2000 & 463,646 & -5.7 & 11.88 & -3.26 & 166.8 & -7.73 \\
\hline 2001 & 361,237 & -22.1 & 11.93 & 4.20 & 140.3 & -1.59 \\
\hline 2002 & 275,468 & -23.7 & 7.92 & -3.36 & 106.8 & -2.39 \\
\hline 2003 & 338,132 & 22.7 & 9.60 & 2.12 & 192.8 & 8.0 \\
\hline 2004 & 385,297 & 13.9 & 13.51 & 4.07 & 179.9 & -6.7 \\
\hline 2005 & 375,398 & -2.6 & -9.09 & -3.27 & 148.4 & -1.7 \\
\hline 2006 & 383,926 & 2.3 & 10.20 & -1.22 & 162.8 & 9.7 \\
\hline 2007 & 526,705 & 37.3 & 11.96 & 1.72 & 230.6 & -4.2 \\
\hline 2008 & 500,277 & -5.0 & 11.78 & -0.02 & 351.9 & 52.60 \\
\hline 2009 & 509,956 & 1.89 & 11.32 & -3.90 & 372.30 & 5.48 \\
\hline
\end{tabular}

Table 2: Tourism statistics reflecting peace responsiveness and conflict sensitiveness of tourism in Nepal.

Source: MoTCA (2010a) 
In this context, the development of timely consensus among political parties in the present political transition phase is a must and utmost priority for peace and stability and to avoid the risk to tourism sector. Tourism may decline precipitously if political conditions appear unsettled (Ritcher and Waugh, as in Kunwar, 2006).

\section{The growing challenges of labor disputes and unionisms in tourism sector:}

The growing unionism amidst the laborers in tourism sector provoked by extreme political ideology, enduring affiliations of trade unions with national political parties, and their growing politicization by mainstream political parties on one side and the exploitative attitude of some monopolistic elite employers against the backdrop of the lack of appropriate labor law and industrial policy under the neo-liberal economic globalization domination on the other side, emerge as the significant structural barriers and hardcore issues in the intricacy of the relationship between employers and employees in tourism sector (Upadhayaya, 2009). Upadhayaya (2010) in this relation reveals a number of confronting incidences that occurred in the hotel sub-sector (table 3).

\begin{tabular}{|l|l|}
\hline February 2009 & $\begin{array}{l}\text { More than a dozen workers were seriously injured in an inhuman attack } \\
\text { with weapons by the management of Hotel Beijing China in Jyatha, Kath- } \\
\text { mandu during peaceful demonstration and continuous negotiation with } \\
\text { the management regarding the implementation of Labor Law. }\end{array}$ \\
\hline December & $\begin{array}{l}\text { Owner of Hotel Maharaja in Kathmandu was physically attacked thrice by } \\
\text { labor union members. } \\
\text { Hotel laborers affiliated with the CPN-M took out a rally in Pokhara de- } \\
\text { manding implementation of Minimum Wage Act. }\end{array}$ \\
\hline January 2008 & $\begin{array}{l}\text { All Nepal Hotel and Restaurant Workers Union (ANHRWA) members of } \\
\text { hotels in Pokhara halted work for three days on minimum wage row deal } \\
\text { demanding a flat increment of Rs 1,300 for all in minimum wage given } \\
\text { to hotel workers. }\end{array}$ \\
\hline January 2008 & $\begin{array}{l}\text { ANHRWA affiliated to CPN-M restricted the entry of tourists for a day } \\
\text { in Nagarkot, a hill spot with 42 hotels situated 32 km northeast of Kath- } \\
\text { mandu. The agitators demanded that their 15-point demands be met and } \\
\text { closed the hotels for four days. Tourists were forced to make a hasty } \\
\text { retreat due to the prevailing uncertainty. }\end{array}$ \\
\hline February 2008 & $\begin{array}{l}\text { Hotels in Chitwan remained closed for weeks owing to the disputes be- } \\
\text { tween the hotels owners and the workers representing Nepal Free Ho- } \\
\text { tel Workers Union affiliated to the General Federation of National Trade } \\
\text { Union (GFONT). The workers' demands were to start levying 10\% service } \\
\text { charge on wildlife tourism package that includes elephant ride, boat ride, } \\
\text { jungle safari, jungle tour, canoeing, bird watching and fee entry to the } \\
\text { national park. }\end{array}$ \\
\hline
\end{tabular}




\begin{tabular}{|c|c|}
\hline $\begin{array}{l}\text { December } \\
2008\end{array}$ & $\begin{array}{l}\text { ANHRWA affiliated to the CPN-M closed Everest Panorama Resort at Da- } \\
\text { man, situated between Kathmandu and Hetauda on the Prithvi Highway, } \\
\text { alleging non-fulfillment of minimum salary as proposed by the govern- } \\
\text { ment. It compelled tourists to leave the hotel prior to the completion of } \\
\text { their stays. }\end{array}$ \\
\hline $\begin{array}{l}\text { November } \\
2008\end{array}$ & $\begin{array}{l}\text { Fifty-eight hotels and resorts of the tourist hub at Nagarkot were shut } \\
\text { down for almost four days demanding an increase of Rs } 1,300 \text { for all } \\
\text { levels of workers by the CPN-M affiliated ANHRWA. Around } 800 \text { tour- } \\
\text { ists staying in } 36 \text { hotels were forced to leave the hotels and/or canceled } \\
\text { their earlier confirmed bookings for stays in the hotels. The hotels were } \\
\text { opened after a negotiation at prime ministerial level in the presence of } \\
\text { minister for home affairs, secretary of Ministry of Tourism and Civil Avia- } \\
\text { tion, representative of Hotel Association of Nepal, ANHRWA representa- } \\
\text { tive. Prior to this negotiation, president of ANHRWA's Bhaktapur wing } \\
\text { received a directive from the Minister for Tourism and Civil Aviation and } \\
\text { followed it. }\end{array}$ \\
\hline $\begin{array}{l}\text { November } \\
2008\end{array}$ & $\begin{array}{l}\text { Closure of Manakamana Cable Car, a famous pilgrimage for Hindu tour- } \\
\text { ists, for a month by All Nepal Security Labor Union affiliated to the CPN-M } \\
\text { demanding to confirm all temporary security guards. }\end{array}$ \\
\hline March 2007 & The owner of Hotel Woodland was injured after disputes with labor union. \\
\hline $\begin{array}{l}\text { December } \\
2006\end{array}$ & $\begin{array}{l}\text { Hotels in Dhulikhel and Nagarkot were closed for three days demanding } \\
\text { that minimum wage standard be maintained and fair treatment ensured. }\end{array}$ \\
\hline October 2006 & $\begin{array}{l}\text { Five associations related to the tourism industry showing their solidarity } \\
\text { to the business community, announced and participated in the shutdown } \\
\text { of all their businesses on October } 17,2006 \text { to oppose severe hardships } \\
\text { from the rising donation drive, extortion and the unreasonable demand of } \\
\text { the unions. The act was aimed at exerting pressure on the government to } \\
\text { come out from its paralyzed state, protect the business community, and } \\
\text { to take immediate measures to stop unfavorable behavior. }\end{array}$ \\
\hline Feb-Aug 2006 & $\begin{array}{l}\text { Hotel Yak and Yeti was closed for almost } 8 \text { months due to a bitter row } \\
\text { between the management and labor unions, and non-cooperation move- } \\
\text { ment by CPN-M affiliated labor union and GFONT. The demands from the } \\
\text { labor unions included fair wages, facilities and permanent status. }\end{array}$ \\
\hline October 2005 & $\begin{array}{l}\text { Thirty workers of the Kathmandu office of the Indian Airlines demanding } \\
\text { permanent status in line with the Labor Act (1992) started a relay hunger } \\
\text { strike from October 19, } 2005 \text { for a month. This strike was backstopped } \\
\text { by the GFONT. }\end{array}$ \\
\hline
\end{tabular}

Table 3: A short list of labor disputes-related incidences and unionization in hotel sub-sector

Source: Primary information collection from the field visit (September 2008-July 2009) and Upadhayaya (2010). 
Amidst the above listed several disputes, the author would like to describe and analyze one case study of labor dispute in Nagarkot in November 2008 in the Kathmandu Valley with its nitty-gritty.

\section{Case study of wage-related disputes at hotels in Nagarkot:}

Nagarkot is a beautiful hill-station situated northeast of Kathmandu at a distance of 32 kilometers. Putting forth their 13-point demand on December 16 , 2007, All Nepal Hotel and Restaurant Workers' Union (ANHRWU) affiliated to CPN-M (which was in the government then) closed down around 58 hotels in Nagarkot from January 16-17, 2008. Club Himalaya, the biggest resort was forced to close from January 14-18, 2010. The closures of all these hotels forced tourists to beat a hasty retreat due to the prevailing uncertainty. Some 800 tourists were forced to leave Nagarkot unpredictably (primary information from the field). The demand for a flat increase of Rs 1,300 for all level of workers after the pay hike structure laid down by the government (table 4) was the major issue apart from other demands like permanent appointment of workers, minimum salary of Rs 4,600 in hotels of all categories (e.g., five star to non star), maximum 8 hours of every day normal duty, annual leave, medical allowance, gratuity, etc.

There is a rule to review salaries of all kinds of workers in the country in every two years.

The government proposed a new salary structure (table 4) for all workers in the country in September 2008.

\begin{tabular}{|l|l|l|l|}
\hline Types of workers & \multicolumn{1}{|c|}{ Basic salary } & Price hike allowance & Total NPR \\
\hline Non-skilled & 3,050 & 1,550 & 4,600 \\
\hline Semi-skilled & 3,100 & 1,550 & 4,650 \\
\hline Skilled & 3,210 & 1,550 & 4,760 \\
\hline Highly skilled & 3,400 & 1,550 & 4,950 \\
\hline
\end{tabular}

For daily wage laborers NPR 190 as minimum salary

Table 4: A new wage structure with minimum salary and allowance

Source: Kantipur, December 1, 2008

The government had earlier decided to raise the minimum salary of workers from NRs 3,300 (NRs 2,200 as basic salary + NRs 1,100 as allowance existed earlier for the lowest wage receiving workers) to NRs 4,600 (table IV) through a directive of the cabinet meeting held on December 8,2008 . The increment of a total of NRs 1,300 was only for those workers who received NRs 3,300 as the lowest income. 
The ANHRWU in Nagarkot itself divided the hotels into three categories - ' $A$ ', ' $B$ ' and ' $C$ ' - and set the minimum salaries at NRs 3,500, NRs 5,000 and NRs 10,000 respectively. The government had increased minimum wages of unskilled workers to NRs 4,600 (table IV) but workers in Nagarkot demanded that hotels not only increase the wages of the lowest income workers but of all workers, even the higher paid ones that fall under category ' $B$ ' and ' $C$ ' (Personal interview with Badri Makaju, Treasurer of Nagakot Naldum Tourism Development Committee on January 17, 2008). With this demand, they closed down the hotels and threatened majadurikaran (unionization) if the demands were not met. The stir was finally pulled back following prime minister-level talks in his office (Himalayan News Service, 2008).

\section{Machhapuchchhre Model Trek: A case study of peace responsive tourism endeavor at village level}

The MMT, covering seven village development committees (VDCs), namely Lahachowk, Ghachowk, Machhapuchchhre, Rivan, Lwanghalel, Sardikhola and Dhital in Kaski district in Western Nepal, is developed as the alternative trekking and hiking route to the Round Annapurna Circuit Trek Route (RACTR) in the Annapurna Conservation Area in Western Nepal on two folds: (a) an organized trekking route with tented camping and (b) a local community-managed homestay tourism product. Although the construction of the road that started in RACTR in 2006 is supposed to be a lifeline for locals in the inaccessible region, the completion of the road construction is predicted to threaten the overall attraction of RACTR for tourists. The comprehensive analysis of the various insights and characteristics of the MMT would be relevant to understand and validate its peace responsive aspects.

\section{Partnership Actions on Transdisciplinary Approach as the Peace Potential of Tourism}

The community-based tourism model on this route is executed by Trekking Agencies' Association of Nepal Western Regional Chapter (TAAN WRC) under a yearlong 'Partnership Actions for Mitigating Syndromes (PAMS)', an interdisciplinary research-related small-scale local development project titled "Developing a community-based tourism model in Kaski district in Western Nepal". The author along with senior researchers of Kathmandu University (KU) and the Swiss National Centre Competence in Research North-South (NCCR), engaged in exploring the relationship between armed conflict, peace and tourism in Nepal, acted as the scientific actors to address the peace perspective of tourism by applying research results to real situations. A number of non-scientific institutions and actors (note 3 ) were collectively involved in the transdiscilplinary approach for interactive and fruitful dialogues and action results. 
The development of the MMT route under PAMS provided an empirical basis for evaluating the potential of transdisciplinary research in triggering social learning processes through concerted actions (TAAN, 2010). Such concerted actions consisted with the organization of three workshops (e.g., the first at a local level at Machhapuchchhre village, the second at regional level in Pokhara and the third at central level in Kathmandu), constructions of basic infrastructures for rural trekking tourism (e.g., five porters' shelters and five trekking campsites at wilderness areas like Meshrom Kharka, Hile, Lalka, Khumai and Pilicho and 25 trail marking boards throughout the whole rural trekking routes), capacitybuilding to 94 women of seven villages on culinary and hospitality skills for offering homestays to visiting guests in community-based village tourism and sketching of a trekking route map and the production of a video documentary titled "Peace through Tourism" (figure 2) (Bechtel, 2010; TAAN, 2010).

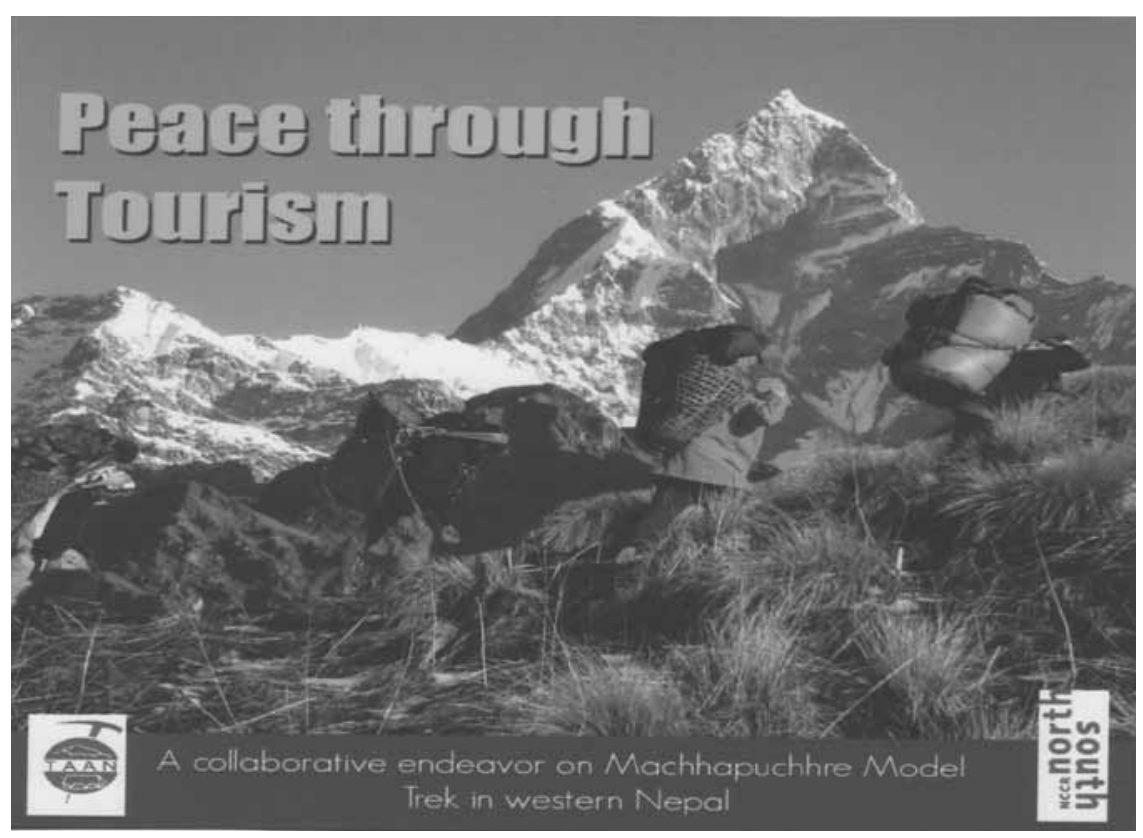

Figure 2: A partnership endeavor for Peace through Tourism

(A video documentary reflecting transdisciplinary approach for peace through tourism)

Source: TAAN, WRC \& NCCR North-South 


\section{Bottom-up participatory planning process}

This MMT route was first explored by TAAN WRC in association with Nepal Tourism Board and five VDCs in this region during Visit Pokhara Year 2007 to conduct a baseline study to check the potentiality for village tourism. This exploration visit was immediately followed by an interaction program organized on Appreciative Participatory Planning and Action (APPA) model at Ghachowk VDC on June 2, 2007. It was attended by 79 participants including local to regional stakeholders (Khatiwada, 2007). There are representations of grassroots people in all programs like infrastructure development, Codes of Conduct (CoC) (note 4) formulation, capacity building activities, and the management of infrastructure after the handover of the product to local communities.

\section{Sustainable and inclusive structure with conflict-sensitive and peace-responsive approach of rural tourism}

The development of the MMT is led by Machhapuchchhre Tourism Development Committee (MTDC) that represents males, females and other marginalized members of local communities with their inclusive representations. The board members of MTDC are represented by a tourism sub-committee of seven village development committees in balanced numbers. The five trekking campsites and porters' shelters have been set up and fixed on five places along the hiking route under the environmentally friendly technical guidelines of ACAP (ACAP, 2009) to keep the impact on the natural environment to a minimum. The MMT route received a total of around 2,000 international tourists arrivals in the year 2010 (information from interview with Mr Rajendra Gurung, President of MTDC in Pokhara, January 2011). With these arrivals, the capacity building of local community to run homestay and rural tourism has started to supplement the meager incomes of around 16,000 mostly subsistence farmers who live in the trekking area.

Realizing the need of a careful indigenous planning and implementations framed with appropriate guidelines to ensure sustainability on the MMT, CoCs were formulated on MMTR after intense debate and discussions among all stakeholders during the KU and NCCR-supported PAMS project.

All local stakeholders have committed themselves to follow and apply conflictsensitive and peace-responsible CoCs that cover five main aspects of tourism, namely planning and managerial, socio-cultural, economic, environmental and those related to safety and security of tourists under the notion of 'peace through tourism' (figure 3) (Upadhayaya and Upreti, 2009). 


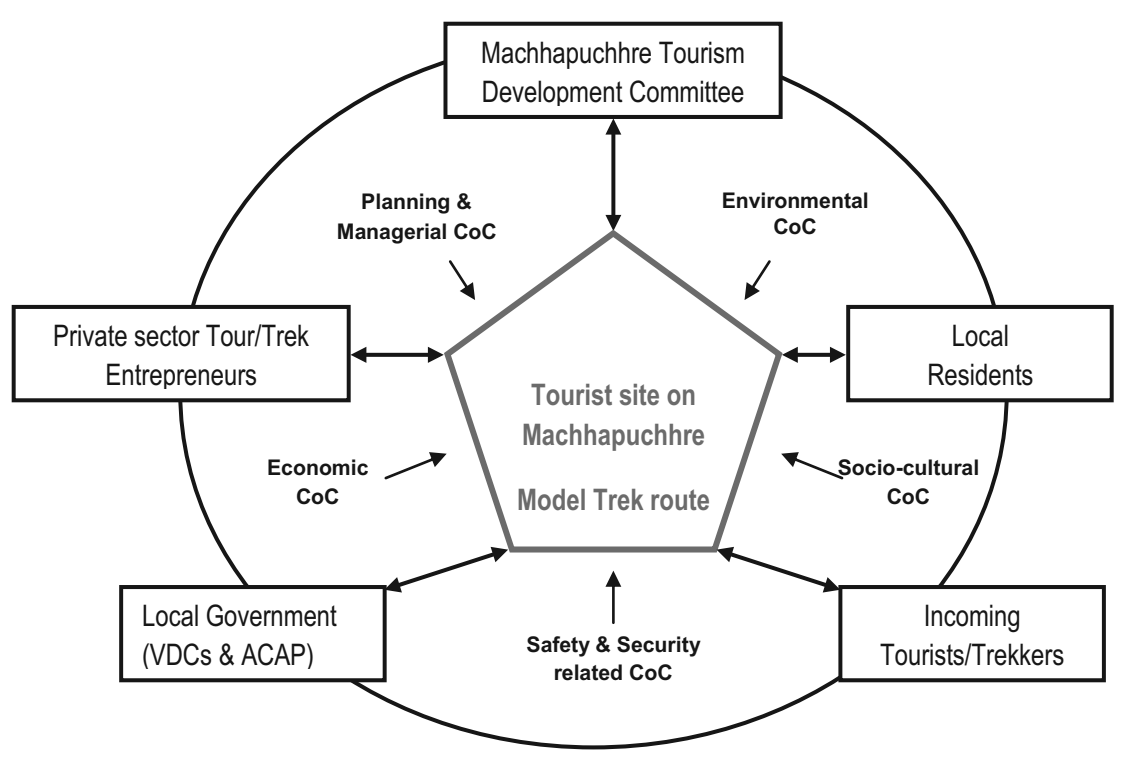

Figure 3: Significant actors in the interlinked composition for the mutually agreed conflict-sensitive tourism CoC at Machhapuchchhre Model Trek route

Source: Upadhayaya and Upreti (2009)

The organization of three workshops, each one at local (Machhapuchchhre VDC), regional (Pokhara) and central (Kathmandu) levels, for discussions and presentations on $\mathrm{CoC}$ is remarkable for its commonly agreed formulation. For long-term sustainability, a Memorandum of Understanding (MoU) on the Directives for the Sustainable Management of Infrastructures has also been jointly signed and exchanged by MTDC and TAAN WRC during the infrastructures handover to MTDC ceremony, a mega event held in Kharpani, Kaski on December 10, 2010 (Sharma, 2009).

\section{Discussions and Conclusions}

Tourism, one of the world's fasted growing economic sectors at a global scale at present (peace time), has raised interest and debate on its potentiality for peacebuilding in its dual forms, viz. industry and/or social force. The state of this debate on peace through tourism linking with relevant case studies is reflected and analyzed. The industrial form of tourism as supported and advocated by advocacy platform commends the role of tourism for employment and income for third world countries like Nepal, but is silent on its equitable growth, a strong ground for sustainable peace-building through tourism. The succeeding cautionary and adaptancy platforms in latter periods followed by knowledge-based platform in recent times appear to replace and strengthen the role of tourism for sustainable 
development and thereby prospective for peace and prosperity. Much of the work from the other three platforms is subjective; the knowledge-based platform positions itself on a scientific foundation in a context where there is no tourism without damage due its resource-consumptive characteristics.

Prolonged poverty, socio-economic injustice, unequal opportunities and marginalization were undeniably the root causes of various political movements (e.g., 1950, 1980 and 1990) and a decade long (1996-2006) armed conflict in Nepal. Neglecting such issues could trigger and re-kindle conflict and jeopardize the whole industry as argued by the cautionary platform of Jafari (1990 and 2005). For this reason, poverty reduction, equitable socio-economic growth and economic development are vital agendas for post-conflict reconstruction, socio-economic security and peace-building in Nepal. Tourism, a peace industry, is sensitive to conflict and responsive to peace. Long-lasting peace and security are vital for a sustainable tourism sector. As tourism is a beneficiary of peace and peace brings hope for travel boom, tourism reciprocally has a key role in peacebuilding by transforming itself in sustainable and participatory forms (Upreti and Upadhayaya, 2010). The economic viability of tourism to eliminate poverty of grassroots disadvantaged people, prevent conflict and violence, and effectuate the socio-economic transformation of the country can largely materialize through tourism by molding it in inclusive, participatory and sustainable characteristics against its longstanding traditional, centralized and monopolistic form as informed earlier by this paper.

Molding tourism with such characteristics also requires a major shift (expansion) of the present centralized form of tourism to rural/village areas which are exotic and enormous but unable to benefit from tourism (Pradhanang, 2009). The prospective of community-based village tourism in its participatory and sustainable forms can be promising in transforming the post-war economy of Nepal into a socio-economy of peace. This is what peace through tourism should really mean. Apart from traditional tourists, the volunteering and philanthropic tourism, as agents of change, are holding promises for Nepal. 'Room to Read' and 'Trek Nepal 2008' can demonstrate such examples in Nepal (Mdfnepal, 2009; Wood, 2010). These need to be scaled up and diverted toward the disadvantaged. However, a careful and critical look on the state of art of Nepalese tourism shows not only various positive signs and future opportunities but also firm challenges for peace through tourism in Nepal.

The state of peacelessness brought about by the unequal structure and complexity of tourism in cases of Upper Mustang, Chitwan and Nagarkot exemplify the rolling of tourism in Nepal through the state of cautionary platform. The remark of Ritcher (1984) on the earlier proposition of Jafari in this context that tourism can spawn divisive conflicts among proponents and opponents of tourism development is rightly related with these examples in Nepal. The case studies 
on the disputes over reopening of jungle resorts inside the Chitwan National Park in 2009 and threats given by the local people to bar the entry of tourists in Upper Mustang in 2010 show the lapses on the implementation of the existing policies and provisions by the government to involve local people on sustainable approach, recycle the revenues of tourism locally and provide benefit to all local stakeholders (both tourists and non-tourists) impartially.

The panicking labor unionization in the hotel sub-sector (example with detailed case study of Nagarkot) and lack of an amicable labor-management relation in the post-conflict period under the verge of its politicization by political parties are the other challenging agendas for lasting peace in tourism sector of Nepal. The strikes should be the last resort and the physical violence and vandalism should always be shunned which are not seen normally applicable in the postconflict period (table III). As a result, there is not only the high prediction on the state of risk to create the negative destination image of Nepalese tourism but also of possible decline in national and international private investments that are crucial for Nepalese tourism to grow smoothly.

However, conflict is not always pathological and dysfunctional but can also be a constructive social process. The institutional strengthening of labor unions in tourism sector by the backstopping of CPN-M led (armed conflict) during the latter phase of the armed conflict and in successive years not only raised greater awareness among the workers, but also provided a strong base for fighting for labor rights and implementing $10 \%$ service charge from January 1, 2007. It helped in introducing the provisions of job permanency after 240 work days, allocation of the minimum wage of NRs 4,600 for permanent staff and NRs 150 as daily wage for temporary wage employees in the tourism sector too, which are positive outcomes of the conflict for tourism and peace indeed.

Nevertheless, the recent policy revisit on tourism by the post-conflict government to facilitate the alternative forms of tourism like private homestay in urban and rural areas and community-based homestay in villages of Nepal through the approval of homestay Sanchalan Karyavidhi 2067 (Homestay Tourism Working procedure 2010) under the policy guidelines of Paryatan Neeti 2065 (Tourism Policy, 2009) for the decentralization of village tourism on the 3Ps (diversifications with new product of village tourism, new people in village tourism and new place of village tourism) modes indicates Nepal's formal entry into the adaptancy platform in the progressive theoretical models of tourism (MoTCA, 2009; MoTCA 2010b). It has attempted to materialize the peace responsiveness of tourism by provisioning to bring much-needed revenues to communities across the country. However, applications of sustainable and participatory tourism strategies integrating with local absorptive capacities and supply linkages to ensure the benefits for people at grassroots levels are indispensable to ensure peace in the real sense. 
In fact, Nepal's enormous village tourism prospect coinciding with trekking and homestay potentials are the most viable forms of generating employments, increasing income and diversifying the benefits on village areas, which constitute a large proportion of the entire geography of Nepal. A number of other studies (Gautam, 2008; Shakya, 2009) also support the conventional wisdom of significant positive relationship between tourism at grassroots of village level and economic growth which (growth) can not only lift agro-based rural households out of poverty but also makes them more secure economically. However, it is not simply village tourism but also the sustainable village tourism, a product resulting from the partnership of different stakeholders in integrated approach, supported by the strategic role of state policies and its honest implementations that matter for peace through tourism in Nepal (Sharma, 2000).

An integrated approach marked by this paper in this context also reveals a transdisciplinary approach by the collaboration of scientific and non-scientific actors based on the knowledge-based platform of the progressive theoretical model of tourism. The roles and actions of all actors (e.g., scientific and nonacademic actors, public and private, academic and industry) in integrated manner can ever become a true peace-builder, both within and outside tourism. The community-based village tourism model on the MMT serves as an alternative example in this endeavor.

The political stability, cooperation among political parties to manage their interparty conflicts and stable governments are preliminary conditions anticipated by Nepalese tourism for smoothly materializing all these vital issues for peace through tourism.

Since there remains little in-depth information on the debate of tourism and peace within its multidimensional interrelationships and difficult discussion issue, there is high need of the expansion of the science of its knowledge through increased research cooperation and interventions.

\section{Notes}

1. CPN-M: The name of CPN-M was changed to the United Communist Party of Nepal (Maoist) or UCPN-M since January 2009 after the merger of the CPN-M with the Unity Center. However, CPN-M is used throughout this article to avoid any confusion about the frequent use of this abbreviation.

2. Methodology:-The secondary source of information included a comprehensive review of published and unpublished literatures, reports and data made available by tourism-related institutions as well as content analysis of several national and international news coverage on conflict and tourism in Nepal. The primary source of information consisted of empirical observations through site visits in Nagarkot in Bhaktapur, Sauraha in Chitwan and Pokhara and its peri-urban 
seven villages in the MMT area in Kaski district. The primary information also included the execution of the author's ongoing PhD research-linked small-scale development project on the community-based tourism in the MMT area in Kaski, research-based paper presentations at workshops followed by interactions and the production of a video documentary titled "Peace through Tourism" (figure III) in 2009 and 2010.

This research-based project titled "Developing a community based tourism model in Kaski district in Western Nepal" covered seven villages (Lahachowk, Ghachowk, Machhapuchhre, Rivan, Lwanghalel, Sardikhola, and Dhital) inhabited by a population of 16,000 of mixed ethnic composition in the peri-urban areas of Pokhara city in Kaski district in Western Nepal. This community-based tourism model was executed on partnership actions between scientific and non-academic actors which made it an innovative model with transdisciplinary approach. In this context the author's paper presentations at three workshops linking with ongoing $\mathrm{PhD}$ research in the field of 'tourism, conflict and peace' followed by a series of interactions and debates were relevant for accessing information and also making triangulation. Among these, the first workshop titled "Postconflict tourism: Challenges and Opportunities" was held in March 2008 in Kathmandu. The other such presentations were one at a regional level (figure $\mathrm{V}$ ) interaction titled "Machhapuchhre Model Trek: Opportunity and Challenges for Community based Rural Tourism" held in July 2009 in Pokhara and the other as a national conference titled "Exploring Alternative Trekking Routes for Peace and Prosperity - An Experience of Machhapuchhre Model Trek route in Kaski District in Western Nepal". The latter was focused on the conflict-sensitive and peaceresponsive tourism codes of conduct. All these presentations were organized jointly by Kathmandu University (KU) and the Swiss National Centre Competence in Research North-South (NCCR) in association with Nepal Tourism Board (NTB) with the latter two interactions also in association with the Annapurna Conservation Area Project (ACAP), Trekking Agencies' Association of Nepal (TAAN) and Machhapuchchhre Tourism Development Committee (MTDC).

3. Non scientific institutions and actors: The non-scientific institutions and actors on the MMT included the members of TAAN WRC in Pokhara as tourism entrepreneurs, Empowering Women of Nepal (Pokhara) as a non-governmental organization in the tourism sector, Annapurna Conservation Area Project (ACAP) and Nepal Tourism Board as facilitators of capacity-building for village tourism operation and environmental guidelines, and other local stakeholders (e.g., seven VDCs as the representatives of local governments, local communities, local mothers' groups and Machhapuchchhre Tourism Development Committee as the core local representative body, etc.) as non-academic local beneficiary actors. 
4. Tourism Code of Conduct ( $\mathrm{CoC})$ : A CoC for tourism is commonly agreed voluntary and self-regulatory (disciplinary) practical guidelines, core values and commitments of local level tourism. Its formulation, finalization with intense discussions, acceptance and applications are significant for the sustainability of tourism.

\section{Acknowledgments}

The research for this publication was conducted within the framework of the Working Package 1 of the Swiss National Centre of Competence in Research (NCCR) North-South: Research Partnerships for Mitigating Syndromes of Global Change, co-funded by the Swiss National Science Foundation and the Swiss Agency for Development and Cooperation. The author would like to thank Dr. Mahesh Banskota of the School of Arts, Kathmandu University, Kathmandu for his valuable comment in reaching the final draft.

\section{References}

ACAP. (2009). Samrakshan Kshetra Vyawasthapan Niyamawali 2053 (Conservation Area Management Regulation 2000). Pokhara: National Trust for Nature Conservation, Annapurna Conservation Area Project (ACAP).

Adhikari, A. (2010, December 31). 2010 turns into 'the year of banda'. The Kathmandu Post, p. 04.

Adhikari, R. (2005), Policy paper on Building Confidence in Tourism through Crisis Management, Kathmandu: Nepal Association of Tour Operators.

Alluri, R.M. (2009). The Role of Tourism in Post-Conflict Peace-building in Rwanda, Bern: Swisspeace.

Arai, T. (2010, July 11). Active Humanism in Practice: Toward a Responsibility-Based Approach to Peace-Building. Paper presented at Toda Institute for Global Peace and Policy Research organized by International Conference on Humanitarian Competition and Global Visioning at Mercure Hotel Sydney.

BBC. (2004). Nepal blockade 'blow to tourism'. Retrieved January 11, 2011 from British Broadcasting Corporation website http://news.bbc.co.uk/go/pr/fr/-/2/hi/south_ asia/3602486.stm

Bechtel, D. (2010). Nepal could reap Swiss tourism harvest. Retrieved November 25, 2010 from

http://www.swissinfo.ch/eng/culture/Nepal_could_reap_Swiss_tourism_harvest. html?cid=8531654

Bhatta, S. (2009, July 24). Mantri Ekatira Mantralaya Arkotira (Minister toward one side, Ministry toward another). Nagarik, p. 1. 
Bhattarai, B. M., \& Dahal, B.M. (Eds.). (2007). Report on Peace and Press: Vital Forces for Tourism Development, Kathmandu: Nepal Travel Media Association (NTMA).

Bhattarai, K., Conway, D., \& Shrestha, N. (2005). Tourism, Terrorism and Turmoil in Nepal. Annals of Tourism Research, 32(3), 669-688.

Bodhi, V.B. (2008). The Buddha and His Message: Past, Present and Future. Kathmandu: Embassy of Sri Lanka.

D’Amore, L. (1988). Tourism - A vital force for peace. Annals of Tourism Research, 15(2), 269-71.

D’Amore, L. (2007). World \& I: Innovative Approaches to Peace, (pp. 64 - 73). Summer.

Dhakal, D. P. ( 2005). Replicating Rural Tourism Development Model. In: CN. Kannel, \& D. Sherpa (Eds.), Rural Tourism Development Process \& New Products (pp. 103 - 107). Kathmandu: United Nations Development Programme \& Tourism for Rural Poverty Alleviation Programme.

Dhakal, D.P, Khadka, M., Sharma, S., \& Choegyal, L. (2007). Lessons learned: Nepal's experience implementing sustainable rural tourism development model of Tourism for Rural Poverty Alleviation Programme. Retrieved January 13, 2011 from Mountain Forum Web site Web site: http//: www.mountainforum.org

Din, K. H. (1988). Tourism for Peace Desires and Attainability. In L. D’Amore., \& J. Jafari (Eds.), Tourism: A vital force for peace (A pre-conference publication) (pp. 75 - 81). L.J. D’Amore and Associates.

DNPWC. (2004) Rastriya Nikunja tatha Banyajantu Samrakshanko Antarik Karyavidhi (Internal Working Procedures of National Parks and Wildlife Conservation). Kathmandu: Department of National Parks and Wildlife Conservation (DNPWC).

Edgell, D.L. (1990). International Tourism Policy. New York: Van Nostrand Reinhold.

Eriksson, J., Noble, R., Pattullo, P., \& Barnett, T. (2009). Putting Tourism to Rights - A Challenge to human rights abuses in the tourism industry. London: Tourism Concern.

Galtung, J. (1996), Peace by Peaceful Means, Peace and Conflict, Development and Civilization. United States: Sage Publications.

Gautam, B. P. (2008). Economic Impact of Tourism Finance in Nepal. Economic review: Occasional Paper. Kathmandu: Nepal Rastra Bank.

Grandon, R. (2007). Nepalese Tourism: the Challenges. Kathmandu: Nepal Association of Tour and Travel Agents.

Higgins-Desbiolles, F. (2006). More than an industry: tourism as a social force. Tourism Management, 27, $1192-1208$.

Higgins-Desbiolles, F., \& Blanchard, L. (2010). Challenging Peace through Tourism: Placing 
Tourism in the context of Human Rights, Justice and Peace. In O. Moufakkir., \& I. Kelly (Eds.), Tourism, Progress and Peace (pp. 35-47). Wallingford: CAB International.

Himalayan News Service. (2008, November 27). Prachanda helps Nagarkot to get back in business. The Himalayan Times, p. 11.

IIPT. (2011a). Amman Declaration on Peace Through Tourism. Retrieved January 15, 2011 from International Institute for Peace Through Tourism Web site: http://www.iipt.org/ globalsummit/ammandeclaration.html

IIPT. (2011b). Tourism a Global Peace Industry. Retrieved January 15, 2011 from International Institute for Peace Through Tourism Web site: http://www.iipt.org

Issac, R. K. (2010). Palestinian Tourism in Transition: Hope, Aspiration, or Reality? In O. Moufakkir, A. Gelbman, D. Timothy, \& I. Kelly (Eds.). The Journal of Tourism and Peace Research (pp. 16-26).Stenden University: The International Centre for Peace through Tourism Research.

Jafari, J. (1990). Research and Scholarship: the basis of tourism education. The Journal of Tourism Studies, 1(1), $33-41$.

Jafari, J. (2005). Bridging Out, Nesting Afield: Powering a new platform. The Journal of Tourism Studies, 16 (2), $1-5$.

Khatiwada, S. S. (2007). Feasibility Study Report of Proposed Machhapuchchhre TAAN Model Trek. Pokhara: Trekking Agents Association of Nepal, Western Regional Chapter.

Kunwar, R. R. (2006). Tourists Tourism: Science and Industry Interface. Kathmandu: International School of Tourism and Hotel Management.

Leitner, M.J. (1999). Promoting Peace Through Intergenerational Tourism. Tourism Recreation Research, 24(1), 53-56.

Mdfnepal. (2009). Trek Nepal 2009. [Brochure]. Kathmandu: Author.

Mihalic, T. (1996). Tourism and Warfare - the case of Slovenia. In A. Pizam, \& Y. Mansfeld (Eds.). (1996). Tourism, crime, and international security issues (pp. 231- 246). Chichester: John Wiley \& Sons Ltd.

Mishra, H. R. (1982). Balancing human needs and conservation in Nepal's Royal Chitwan National Park. Ambio, 6: 246-257.

MoTCA. (2009). Paryatan Neeti 2065 (Tourism Policy 2009). Kathmandu: Ministry of Tourism and Civil Aviation (MoTCA).

MoTCA. (2010a). Nepal Tourism Statistics 2009. Kathmandu: Ministry of Tourism and Civil Aviation (MoTCA).

MoTCA. (2010b). Homestay Sanchalan Karyavidhi (Homestay Operation Work Procedure). Kathmandu: Ministry of Tourism and Civil Aviation (MoTCA). 
Moufakkir, O., \& Kelly, I. (Eds.). (2010). Tourism, Progress and Peace. Wallingford: CAB International.

Müller-Böker, U. (1999). The Chitwan Tharus in Southern Nepal. An Ethnoecological Approach. Kathmandu: Nepal Research Centre.

Müller-Böker, U. (2000). Ecotourism in Nepal: The Example of the Royal Chitwan National Park. In R. Thapa, \& J. Baaden (Eds.), Nepal Myths and Realities (pp 100-118). Delhi: Book Faith India.

Nepal, S.K. (2003). Tourism and the Environment. Perspectives from the Nepal Hiamalaya. Lalitpur: Innsbruck, Wien, München.

NTB. (2005). Sustainable Rural Tourism for Improved Livelihood of Local Communities With special reference to Tourism for Rural Poverty Alleviation Programme, Unpublished draft paper to discuss for a regional interaction program. Kathmandu, Nepal, 21 November. Available from Nepal Tourism Board (NTB).

NTB. (2008). In focus 2008. Kathmandu: Nepal Tourism Board (NTB).

Pandey, R. J. (2008). What should we do to practice Community Based Pro-poor Tourism: Lessons to be learned from TRPAP? In P. Sharma (Eds.), Vision and Mission of Village Tourism (pp. 32-38). Kathmandu: Village Tourism Promotion Forum-Nepal.

Pokharel, S. \& Paudel, D. (2010). Upper Mustang locals threaten to bar tourists. Republica, p. 8.

Post Editorial (2008, July 10), 'Post Editorial', The Kathmandu Post, p. 4.

Pradhanang, S.B. (2009). Village The New Tourist Destination of Nepal. New Delhi: Adroit Publishers.

Rees, S. (2003). Passion for Peace Exercising Power Creatively. Sydney: University of New South Wales Press Ltd.

Ritcher, L. K. (1984). The Politics of Tourism in Asia. Honolulu: University of Hawaii Press.

Salazar, N.B. (2006). Building a 'culture of peace' through tourism: reflexive and analytical notes and queries. Universitas Humanistica 62, 319-333.

Satani, K. (2003). Peace through tourism: How can tourism lead peace? MA Dissertation, University of Bradford.

Shakya, M. (2009). Risk, Vulnerability and Tourism in Developing Countries: The Case of Nepal. Bochum: Institute of Development Research and Development Policy.

Sharma, P. (Ed.) (2000). Tourism as Development Case Studies from the Himalaya. Kathmandu: Himal Books and STUDIENVerlag Innsbruck-Wien-München.

Sharma, S. (2009, December 15). Kaskika sat gabisa padmarga gantavya, Machhapuchchhre Model Trek Samudayalai (Seven VDCs of Kaski as trekking destination, Machhapuchchhre Model Trek handed over to community). Kantipur, p. 13. 
Sharma, S. \& Upadhayaya, P.K. (Eds.). (2008). Report on the proceedings of National Workshop on Post-Conflict Tourism in Nepal: Opportunities and Challenges, Kathmandu: Human and Natural Resources Studies Centre, Kathmandu University \& Swiss National Centre of Competence in Research (NCCR) North-South.

Sherpa, M. N. ( 2005). Appreciative Inquiry in Sustainable Rural Tourism Development. In: CN. Kannel, \& D. Sherpa (Eds.), Rural Tourism Development Process \& New Products (pp. 77 - 82). Kathmandu: United Nations Development Programme (UNDP) \& Tourism for Rural Poverty Alleviation Programme (TRPAP).

Shrestha, P.M., \& Shrestha, M. (2008). Workers shut Nagarkot hotels. The Kathmandu Post, p. 1, 3.

TAAN. (2010). Final report of PAMS tourism project (PAMS No. SAS -2_05) on 'Developing a community based tourism model in Kaski districts in Western Nepal'. Pokhara: Trekking Agencies' Association of Nepal (TAAN) Western Regional Chapter.

Tarlow, P.E. (2006). A Social Theory of Terrorism and Tourism. In Y. Mansfeld \& A. Pizam (Eds.), Tourism, security and Safety (pp. $33-47)$, Oxford: Elsevier.

The Himalayan Times. (2009a, July 31). Chitwan hotel shutdown: Staff left in lurch Hoteliers in Sauraha in favour of closing the hotels inside national park. The Himalayan Times, p. 1.

The Himalayan Times. (2009b, August 9). Jobless hotel employees, kin on warpath. The Himalayan Times, p. 11.

Tripathi, B. (2009, September 23). Paryatan Barsha 2011 Samma Hotel Chalna Dinuparne Mag (Hotels to be allowed to run till Tourism Year 2011). Kantipur, p. 15.

Upadhayaya, P. K. (2008). Lasting Peace as the Precondition for Sustainable Tourism. Nepal Travel Trade Reporter, X (51), 24-25.

Upadhayaya, P.K. (2009). Post Conflict Tourism in Nepal: Challenges and Opportunities for Preventing Latent Conflict. The GAZE JOURNAL OF TOURISM AND HOSPITALITY, 1(1) 2009: 28-42.

Upadhayaya, P.K. (2010). Labor Disputes in Tourism Sector: A Critical Look in Nepalese Tourism During and After Armed Conflict. Journal of Tourism and Hospitality Education, 1(1) 2011: 27- 52.

Upadhayaya, P. K., Müller-Böker, U., \& Sharma, S. R. (2010). Tourism amidst Armed Conflict: Consequences, Copings, and Creativity for Peace-building through Tourism in Nepal. The Journal of Tourism and Peace Research. 1(2), 22-40.

Upadhayaya P.K. \& Upreti B.R. (2009). Application of Conflict Sensitive Code of Conducts at Machhapuchchhre Model Trek - Obligations and Challenges. National Conference on Exploring alternative trekking routes for peace and prosperity, An experience of Machhapuchchhre Model Trek route in Kaski district in western Nepal, 14 December 2009, Kathmandu, Kathmandu: TAAN, NCCR North-South and NTB. 
Upreti B.R. \& Upadhayaya P.K. (2010). Armed Conflict and Tourism: Cost and Consequences in Nepal. In: A.C. Settle, I. Niazi, S. Siddiq, \& U.T. Haroon (Eds.), Peace and Sustainable Development in South Asia Issues and Challenges of Globalization (pp. 235 - 261). Lahore: Sang-E-Meel Publications (Sustainable Development Policy Institute).

Wood, J. (2010). Leaving Microsfot to Change the World, An Entrepreneur's Odyssey to Education the World's Children. Retrieved January 15, 2010 from Room to Read Web site: http://www.leavingmicrosoftbook.com/author.html 